\title{
Self-Regulated Learning Strategy Instructions in Reading Comprehension Skill Learning During Outbreak Era
}

\author{
Ratih Laily Nurjanah \\ English Literature Department, Universitas Ngudi Waluyo \\ e-mail: ratih.laily@gmail.com \\ Mochamad Rizqi Adhi Pratama \\ English Literature Department, Universitas Ngudi Waluyo \\ e-mail: rizqi.adhi@unw.ac.id
}

\begin{abstract}
The online learning should be limited by principles and apply proper strategies. One of them is Self-Regulated Learning (SRL) strategy. Applying this strategy must be guided by proper instructions and procedures. In reading skill teaching and learning, this strategy is considered suitable to make students learn independently without letting them lost in the processes. This study aims to; 1) develop tasks instructions on reading comprehension skill to help students learn independently during outbreak era, 2) get students' perspectives on how SRL works on them. The method is research and development cycle. The students' perspectives are measured using Likert scale. The results showed that there need to be specific and clear instructions stating time, purposes of the tasks, giving students log to monitor their learning process, encouraging them to get help from lecturers or peers, and encouraging themselves to evaluate the process to find proper strategy for them.
\end{abstract}

Keywords: English teaching, reading comprehension skill, Self-Regulated learning

\section{INTRODUCTION}

Covid-19 outbreak forces lecturers to create a new environment of teaching and learning where students are able to keep up with the materials, improve their skills, and at the same time reach the learning objectives without being stressed out. Online learning or online classroom is considered as the best way to keep the teaching and learning process running by maximizing every media and the use of internet.

These kinds of online learning activities force students to study independently. The roles of lecturers in this learning process are as motivators and guidance. Lecturers have to 
Ratih Laily Nurjanah \& Mochamad Rizqi Adhi Pratama

make sure students keep working on their progress of learning without being depressed. However, beyond all the media and the assistance of the internet, one of things should be considered is the use of proper strategies.

In this case, university students are those expected to be able to improve themselves without being dependent on the lecturers. In fact, English learning needs to be supported by the roles of lecturers as guides and controllers in terms of keeping the learning on track.

In teaching reading comprehension to students in higher education, students need to be exposed to various kinds of texts with various level of difficulty. It is because students might know how to read but they have never learned good reading skills (Royse, 2001). Reading comprehension has more something to do if it is compared to ordinary reading as it requires the students to have more skills rather than reading sentences and paragraphs. According to Hart, E. R., \& Speece (1998), "one of the greatest demands on students attending postsecondary institutions is the comprehension of many different and difficult texts". This is revealed that the demand of reading comprehension skill for students in higher education is significantly high and prominent.

Several notions have been proposed by scholars especially in assisting teaching reading comprehension. Ooi, Choo, \& Ahmad (2011) argued that reciprocal teaching strategy contributes significant impact on students' reading comprehension. The study reveals pedagogical implications especially for ESOL teachers that they are expected to model reciprocal teaching strategies in their reading class. Additionally, Ahmadi \& Gilakjani (2012) also conducted a study on the effectiveness of reciprocal teaching strategies in improving English reading comprehension. This study was aimed at defining the key terms, models of reading process, review reading process, and reading strategies, discussing cognitive and metacognitive strategies, reading comprehension, elaborating reciprocal teaching and its theoretical framework, mentioning the related research, and stating the relationship between reciprocal teaching and reading comprehension. The findings showed that reciprocal teaching had a considerable positive effect on the English reading and usage of the four main metacognitive reading strategies of EFL students.

Reciprocal teaching has been defined in various ways by scholars. Rosenshine, B., \& Meister (1994) defined reciprocal teaching as an instructional strategy that directly teaches students to apply metacognitive thinking as they make meaning from a text. Carter (1997) argued that reciprocal teaching parallels the new definition of reading that describes the process of reading as an interactive one, in which readers interact with the text as their prior experience is activated. Previous experience is used as a channel when readers learn new information, ideas, and arguments. Most essentially, readers establish meaning of the text by referring to the previous experience to confirm, distinguish, or trace what the author suggests. This is what advanced and excellent readers, unless the content would not have meaning.

The way in which students construct the meaning of a text indicates that reciprocal teaching belongs to constructivist learning. The term constructivism refers to the idea that learners construct knowledge for themselves both individually and socially (Museum \& Israel, 1991). It reveals that the teaching and learning process of constructivist learning is supposed to provide the students with materials and process which enable them to recall their 
previous knowledge and experience in order to construct the new knowledge contained in the meaning of the text they are reading.

In contrast to self-regulated learning (SRL), the three words imply the emphases of autonomy and control to monitor, directs, and regulates actions toward goals of information acquisition, expanding expertise, and self-improvement (Museum \& Israel, 1991). Students are required to be independent in constructing their knowledge to achieve the main goal of the learning, in this case the reading comprehension activity. "...researchers and educators who seek to understand how students become adept and independent in their educational pursuits (Museum \& Israel, 1991).

Instead of independence, SRL also contributes various benefits for students. SRL is useful to make the students reflective and metacognitive in three times: during initial learning, while troubleshooting, and teaching others to use strategies (Paris, S. G., Lipson, M. Y., \& Wixson, 1983). As the students are expected to be independent in their own learning, they should be always motivated to exert effort, to persist when facing difficulty, to set goals, and to feel self-efficacy with their own accomplishment. They need the volitional control to avoid destruction and stay on track (Corno, 1993). Additionally, the students also get benefit in using emotion control, such as reassuring self-speech, to limit anxiety about task difficulty (Kuhl, 1984).

The main features of reciprocal teaching apparently parallels with the main feature discussed in this study, self-regulated learning. Both have dealt with cognitions of the students, however, self-regulated learning has more something to do on students' behavior in their learning. The behavior discussed here includes the way how students behave independently in their learning. In this case, students independently employ their previous knowledge and experience in constructing meaning of the text they are reading. In other words, the level of dependence of the students toward the teachers' knowledge is lessened as they are expected to become a self-constructor of their own knowledge based on the given materials ad process of learning.

In relation to present pandemic situation and outbreak era, the notion of independent learning is strongly blown as the limited communication and access to the teachers' instructions and knowledge. Nowadays, learning process is done online via various types of media such as zoom meetings, google meet, etc. In this process of learning, especially reading comprehension, the reading activity is impossible to do within the classroom hours. The students are required to train their reading comprehension skill on their own.

According to the background explained above, this study aims to; 1) develop tasks instructions on reading comprehension skill to help students learn independently during outbreak era, 2) get students' perspectives on how SRL works on them.

\section{LITERATURE REVIEW}

Teaching reading skill in EFL is considered a challenge shown by many researches proposing methods, approaches and media to engage students in reading activities started from young readers to adult readers. Later on, along with the development of era and technology, digital media are used effectively to teach reading skill for EFL students. The media are also designed to be used independently by students to support the activity of independent learning.

JELTL (Journal of English Language Teaching and Linguistics), 5(2), 2020 


\section{Ratih Laily Nurjanah \& Mochamad Rizqi Adhi Pratama}

One of those media is an audiobook developed to guide and accompany students in reading activity that was stated to help students gain information, develop literacy skills (reading and writing), and even listening skill (Imawan \& Ashadi, 2019).

Other research accounts for the use of DRTA (Direct Reading Thinking Activities) in teaching reading comprehension compared to DRA (Direct Reading Activities) on Junior High students. This research shows that DRTA is more effective than DRA since the former not only helps students comprehend a text but also involves students on critical thinking activities (Utami \& Sugirin, 2019).

The use of textbook is commonly found in classroom. Teachers or lecturers are commonly found to use textbook while also supported by additional aids. Although textbook is considered monotonous for some reasons, but as long as the teachers or lecturers are not bound by the textbook by exploring the aids, the lesson will still be accepted by students (Harper, 2019).

One of the learning strategies proposed for adult learners like university students is Self-Regulated Learning (SRL). Self-regulated learning (or self-regulation) refers to the process whereby learners personally activate and sustain cognitions, affects, and behaviors that are systematically oriented toward the attainment of learning goals according to Zimmerman and Schunk (Brandmo \& Berger, 2013)

SRL strategy of Zimmerman includes 3 phases in the process (Panadero \& AlonsoTapia, 2014);

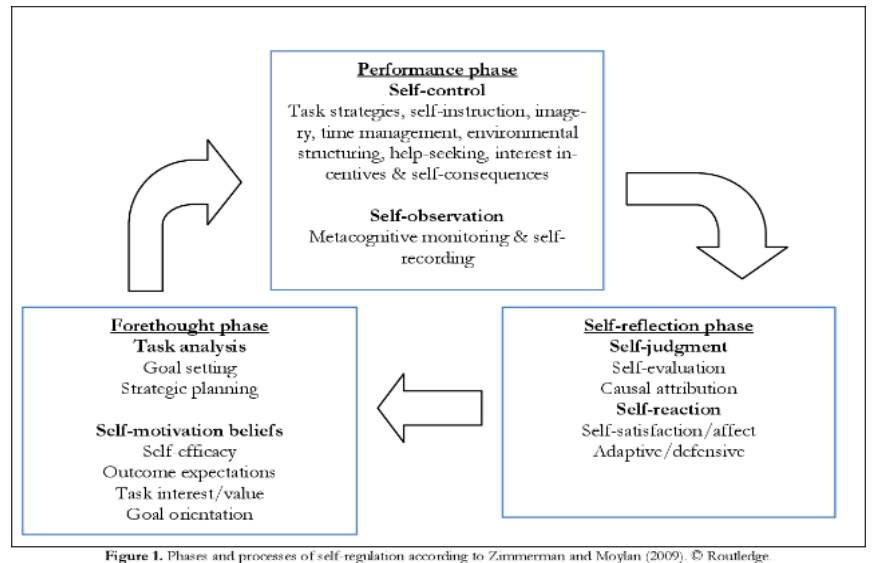

Figure 1. Phases of Self-Regulated Learning

\subsection{Forethought and planning phase}

The activities happen in this phase are goal setting and strategic planning. Students are expected to get themselves familiar with the task, comprehend the instructions, and set their own goals in completing the task. As students set goals, they become more conscious of their own strengths and weaknesses; moreover their approach to learning becomes more reflective (Bloom, 2013). Efficacy establishes motivation that helps students in understanding how expectations affect student achievement. In expectancy-value theory, motivation is a function of expectations of success and perceived value. Attribution theory focuses on the causal attribution of learners to explain the results of an activity, and classifies in terms of 
their locus, stability and control. Social cognitive theory emphasizes self-efficacy as an important key of motivated action (Nugraha, Degeng, Hanurawan, \& Chusniah, 2017)

\subsection{Performance monitoring phase}

Here, students can set their own strategies to complete the task by doing self-trying considering the environment condition, managing the time, help-seeking, interest incentives $\&$ self-consequences.

\subsection{Reflection on performance,}

Students evaluate their own performance in completing the task and self-reflect their own results. In this phase, students manage their own emotion in terms of satisfaction or disappointment. Then the cycle starts from the beginning. (Wandler \& Imbriale, 2017) proposed strategies to support the cycles of SRL by Zimmerman;

1. Strategy 1: Introduce SRL strategy to students to make students have the same vision with teachers or lecturers. Giving module containing how to set learning goals, time management, test preparation and note-taking strategies is considered helpful.

2. Strategy 2: Include Study Log to the learning activities. This log or journal is used as record of students' own progress. The log can be in forms of online spreadsheets or others. This log will help students observe their study habits.

3. Strategy 3: Encourage students to SRL throughout the whole semester instead of at the beginning only. This shows that teachers or lecturers still have role as a motivator to make sure students are not lost on their own processes of learning. In case of online learning, motivation should be given in every task or activity given.

4. Strategy 4: Remind students via text messages or chatting apps. Since students are under the guidance of lecturers or teachers, reminder is taken important. This helps students who do not spend most of their time in online environment. Sending a text containing a list of assignments need to be done with the deadline will be really helpful when face-to-face classroom is impossible to conduct. Using text message reminders can influence students in the performance phase of self-regulation.

5. Strategy 5: Use scaffolding strategy where teachers or lecturers provide support mechanism to guide students learning. This helps students in terms of seeking help either from lecturers or peers. Scaffolding is seen effective in the performance phase of self-regulation, especially in the areas of task strategies, time management, interest enhancement, and help seeking.

6. Strategy 6: Encourage help-seeking. Help-seeking is done by students to get additional support from peers or more knowledgeable others. In the online academic environment, help seeking typically comes in the form of information searching, formal query, or informal query through web searches using search engines, information gathering websites, textbooks, or other documents.

The problems happen nowadays in university students learning during quarantine era are where face-to-face classroom is impossible and the spread of the internet network may be different from one student to another. Leading students to apply self-regulated strategy can be used as an alternative to keep students involved in learning process without depending on their lecturers much. In reading class, where actually the activities depend on students' motivation, SRL is assessed as a proper strategy. This application must be followed by 
Ratih Laily Nurjanah \& Mochamad Rizqi Adhi Pratama

providing proper instructions either in form of direct instructions or along with a module or worksheets.

Reading skill as one of language skill, in this case, is considered to be the most appropriate skill to apply SRL in the learning process. University students nowadays, which are supposed to be high-level readers, still think that reading skill is sometimes difficult moreover when it relates to reading comprehension.

The tasks related to reading comprehension still become problems for university students especially vocabulary knowledge or mastery (Laily, 2018).

\section{RESEARCH METHODS}

\subsection{Research Design}

The method of this research is research and development method proposed by Overdijk (Overdijk, 2009)

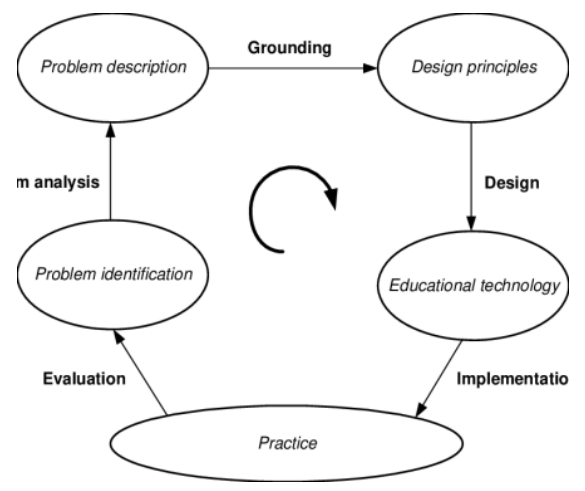

Figure 2. Research and Development Cycle

The cycle starts from describing problem as stated in the previous session. From the problems, the principles designed are;

1. Introduce students to SRL,

2. Create activities accommodating the learning processes,

3. Create instructions according to the activities,

4. Put the instructions with a module or worksheets.

The design produces an educational technology, in this case is module or worksheets given to students to guide them in the learning process of reading skill.

In the implementation of the SRL strategy, the module or worksheets are then used as media in learning practices.

Next step is evaluation where students are expected to give their perception on the module or worksheets. The results of the evaluation are used as foundation for another development cycle.

\subsection{Participants}

Students of $2^{\text {nd }}$ and $4^{\text {th }}$ semester of English Literature Department of Universitas Ngudi Waluyo with total 22 students. 


\subsection{Instruments}

The instruments used in this research is questionnaire distributed to students to get their perspectives on SRL strategy in reading skill measured with Likert Scale from Strongly disagree (1) to Strongly Agree (5). The statements are;

1. The SRL strategy motivates me to be more independent.

2. The SRL strategy helps me to be more organized

3. The SRL strategy helps me know my strength and weakness in learning.

4. The SRL strategy improves my interest in completing tasks

5. The lecturer always motivates me to improve reading comprehension skill

\subsection{Data Analysis} students.

The data then analyzed by overviewing the results from questionnaire distributed to

\section{FINDINGS AND DISCUSSION}

The results of this research are instructions that are used in SRL strategy to teach reading skill. Since the strategy has 3 phases, each phase is indicated by specific instructions. To keep the students on track, pre-learning instruction is given, such as;

1. "Please read the text about Self-Regulated Learning below."

This instruction leads students to get familiar with strategy they will apply in the learning processes.

2. "Complete this diagram about Self-Regulated Learning"

This instruction helps students evaluate how far they comprehend the strategy itself.

These instructions are meant to introduce SRL strategy to students before they apply it.

\section{Phase 1 "Forethought and planning phase"}

The instructions that may occur;

1. "In this session, you are expected to be able to identify the main sentence of a paragraph"

Stating this in the beginning of every unit will help students know their targets from lecturers or teachers. This simple information may seem unimportant but deep down it communicates what lecturers or teachers want from the students. By knowing the expectation, students can set their expectation or goal based on their teachers' or lecturers'.

2. "Please read the text below and answer 10 questions related to the text"

\section{The Three Bears}

10minutes

Stating the time given to complete the task will give students an overview on how they should complete it. For example, they will imagine that 10 minutes divided by 10 questions meaning that they have to answer each question in less than 1 minute. But they still have a text to read besides answering the questions. They will consider whether they have to read the text first or reading the questions first. 
Ratih Laily Nurjanah \& Mochamad Rizqi Adhi Pratama

3. "Pay attention to the text below. Complete the table based on the text." (10minutes) State the task clearly. Instead of just "answer the questions", state the task specifically. If there are more than 1 tasks based on 1 text, split the instructions as in number 4 below.

4. "Please, read the text below." (3minutes)

"Answer these following questions" (5minutes)

"Complete the table" (3minutes)

5. "Before reading the text, please answer this question." (1minute)

The pre-reading questions are given to students to build knowledge before they deal with the text. The questions given can help students to relate to their own prior experiences or prior knowledge. This strategy applies 'scaffolding" strategy to support.

\section{Phase 2 "Performance monitoring phase".}

In this phase, students log strategy is applied to make students able to review their own progress and achievement. The tasks record of students is expected to help students find the most suitable strategies they can use since each student may have different preferences. These results indicated that it is necessary to find out the most effective strategies for different students or teaching environments, so that we can save psychological resources and promote academic performance to the greatest extent ( $\mathrm{Li}, \mathrm{Ye}$, Tang, Zhou, \& Hu, 2018). The log may occur like;

Table: 1 Students' Log

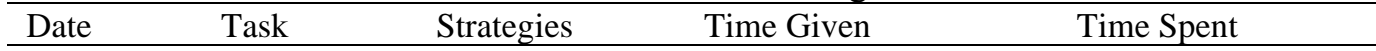

The "Tasks" column is filled with tasks given by lecturers. For example, "Unit 1 Text 1 Task 1". The "Strategies" column is filled with how students complete the tasks. For example "Read the questions first before read the text" or "Read only the first sentence to identify main sentence." The "Time given" is the time set by teachers or lecturers in the instruction. The "Time spent" is the time spent by students to finish each task. By completing this table, students can monitor their own performance whether or not they can complete the tasks on time. In this phase also, lecturers should give reminder to students about the tasks.

\section{Phase 3 "Reflection on performance"}

After completing their log, students are asked to observe their performance and evaluate which part that needs to be improved and which part they still have difficulties. By observing their performances, students later can decide if they need helps either from peers or lecturers. Lecturers can also encourage students to get help from other sources such as the internet by giving links or topics to be searched. Giving certain guide like this will keep students on the track. 
This will also help students decide which strategies they can use comfortably to complete certain task. Some students may be comfortable when they read the questions first before reading the text and vice versa.

Since learning strategies application may be different from one student to another, the $\log$ will result various strategies. The implementation of this strategy needs lecturers to get involved from the preparation process until the evaluation. Regarding this fact, it is important for lecturers to have a training especially in terms of preparing materials whether in form of modules or worksheets (Ergen, 2017)

From the questionnaire distributed to students, the results showed that;

\begin{tabular}{|c|c|c|c|c|c|c|}
\hline No & Statement & $\begin{array}{c}1 \\
\text { Strongly } \\
\text { Disagree }\end{array}$ & $\begin{array}{c}2 \\
\text { Disagree }\end{array}$ & $\begin{array}{c}3 \\
\text { Undecided }\end{array}$ & $\begin{array}{c}4 \\
\text { Agree }\end{array}$ & $\begin{array}{c}5 \\
\text { Strongly } \\
\text { Agree }\end{array}$ \\
\hline 1 & $\begin{array}{l}\text { The SRL strategy motivates me } \\
\text { to be more independent }\end{array}$ & & & & $\begin{array}{c}81 \% \\
(18 / 22)\end{array}$ & $\begin{array}{c}18 \% \\
(4 / 22)\end{array}$ \\
\hline 2 & $\begin{array}{l}\text { The SRL strategy helps me to } \\
\text { be more organized }\end{array}$ & & & & $\begin{array}{l}100 \% \\
(22 / 22)\end{array}$ & \\
\hline 3 & $\begin{array}{l}\text { The SRL strategy helps me } \\
\text { know my strength and weakness } \\
\text { in learning }\end{array}$ & & & & $\begin{array}{c}68 \% \\
(15 / 22)\end{array}$ & $\begin{array}{l}31,8 \% \\
(7 / 22)\end{array}$ \\
\hline 4 & $\begin{array}{l}\text { The SRL strategy improves my } \\
\text { interest in completing tasks }\end{array}$ & & & $\begin{array}{l}13.6 \% \\
(3 / 22)\end{array}$ & $\begin{array}{c}68 \% \\
(15 / 22)\end{array}$ & $\begin{array}{l}18 \% \\
(4 / 22)\end{array}$ \\
\hline 5 & $\begin{array}{l}\text { The lecturer always motivates } \\
\text { me to improve reading } \\
\text { comprehension skill }\end{array}$ & & & & & $\begin{array}{l}100 \% \\
(22 / 22)\end{array}$ \\
\hline
\end{tabular}

The results of the questionnaire showed that students argue that this strategy makes students be more independent in learning activities because they can study or conduct their own study-time. The SRL strategy also makes them more organized because they have students $\log$ to keep them monitored.

By applying this strategy, students can observe their competencies based on the students log and they can evaluate themselves so they know which strategy is best for them. This will affect their confidence and they become more interested in getting involved in reading comprehension tasks.

Since motivation from lecturers play important role in SRL strategy, students agree that lecturers do not give the motivation in the beginning session but also the whole semester.

Giving students proper strategy is considered important since reading comprehension can be boring for students related to low interest in reading activities. Preparing learning media whether in forms of audio visual or paperwork needs more attention from lecturers. Deciding what tasks should be given needs to be accompanied by clear instructions and well time allotment to prevent students from getting stressed out or exhausted. 


\section{Ratih Laily Nurjanah \& Mochamad Rizqi Adhi Pratama}

SRL strategy, in this study, aims to help students enjoy reading activities by giving them freedom to create their learning environment, teach them to manage their time, and gives them self-confidence.

From lecturers' point of view, SRL demands them to be more creative and wellorganized since they have to make sure the instructions and tasks given are relatable to students and students can follow them well. To prepare teaching and learning media based on this strategy is required specific training so in the future there should be training for lecturers about SRL strategy.

Self-Regulated Learning strategy demands students learn by themselves without being accompanied directly by lecturers. On one hand, this strategy can be advantageous in terms of developing independence of students in learning process. On the other hand, this strategy can also be in effective when it does not come with proper instructions. Students need to know clearly what they have to do with the tasks and what strategy they have to apply.

This is where the pre-reading strategy and reading instructions developed in this study has important role. The pre-reading strategy is used to introduce students to SRL strategy so they have preview in mind what they will deal with. The instructions, in this case, give guide and limit on how students study so they focus on improving their reading skill by completing the tasks given.

\section{CONCLUSION}

Self-Regulated Learning strategy is considered appropriate for the independent learning method since this strategy requires students to be more creative on learning process. The instructions of the tasks given during this strategy application also determines the success of the students in applying the strategy. Clear and specific instructions are given to help students become familiar with the tasks, comprehend the tasks, and manage their time to complete the task. Applying this strategy also allows students to evaluate themselves and assess whether their competencies meet the standards given by lecturers. Thus, it is important for lecturers to get to know SRL well and get trained for developing the materials or tasks with SRL strategy.

\section{REFERENCES}

Ahmadi, M. R., \& Gilakjani, A. P. (2012). Reciprocal Teaching Strategies and Their Impacts on English Reading Comprehension, 2(10), 2053-2060. https://doi.org/10.4304/tpls.2.10.2053-2060

Bloom, M. (2013). Self-regulated learning: Goal setting and self-monitoring. The Language Teacher, 37(4), 46. https://doi.org/10.37546/jalttlt37.4-6

Brandmo, C., \& Berger, J. (2013). Fostering Self-Regulated Learning: An Introduction. Journal of Cognitive Education and Psychology, 12(2), 127-137. https://doi.org/10.1891/1945-8959.12.2.127

Carter, C. (1997). Why reciprocal teaching? Educational Leadership, 54(6), 64-71.

Corno, L. (1993). The best-laid plans: Modern conceptions of volition and educational research. Educational Researcher, 22(2), 14-22.

Ergen, B. (2017). The Effect of Self-Regulated Learning Strategies on Academic 
Self-Regulated Learning Strategy Instructions in Reading Comprehension

Achievement: A Meta-Analysis Study, (February 2019). https://doi.org/10.14689/ejer.2017.69.4

Harper, J. (2019). Supplementing Coursebooks--How, Why, and to What Effect: A Case Study. Journal of English Language Teaching and Linguistics, 4(2), 207. https://doi.org/10.21462/jeltl.v4i2.283

Hart, E. R., \& Speece, D. L. (1998). Reciprocal teaching goes to college: Effects for postsecondary students at risk for academic failure. Journal of Educational Psychology, 90(4), 670.

Imawan, M. R., \& Ashadi, A. (2019). Audiobooks for Assisting EFL Students in Reading Independently. Journal of English Language Teaching and Linguistics, 4(1), 77. https://doi.org/10.21462/jeltl.v4i1.198

Kuhl, J. (1984). Volitional aspects of achievement motivation and learned helplessness: Toward a comprehensive theory of action control. In Progress in experimental personality research (Vol. 13, pp. 99-171).

Laily, R. (2018). The Analysis on Students' Difficulties in Doing Reading Comprehension Final Test. Metathesis: Journal of English Language, Literature, and Teaching, 2(2), 253. https://doi.org/10.31002/metathesis.v2i2.958

Li, J., Ye, H., Tang, Y., Zhou, Z., \& Hu, X. (2018). What are the effects of self-regulation phases and strategies for Chinese students? A meta-analysis of two decades research of the association between self-regulation and academic performance. Frontiers in Psychology, 9(DEC), 1-13. https://doi.org/10.3389/fpsyg.2018.02434

Museum, T., \& Israel, J. (1991). Constructivist Learning Theory, (October), 15-22.

Nugraha, R. A., Degeng, N. S., Hanurawan, F., \& Chusniah, T. (2017). ORIGINAL RESEARCH ARTICLE Open Access The Effect Of Self-Regulated Learning On High School Students' Self-Efficacy, 07(April), 13612-13617.

Ooi, T., Choo, L., \& Ahmad, N. (2011). Effects of Reciprocal Teaching Strategies on Reading Comprehension, 11(2), 140-149.

Overdijk, M. (2009). Appropriation of Technology for Collaboration from Mastery to Utilisation.

Panadero, E., \& Alonso-Tapia, J. (2014). How do students self-regulate? Review of Zimmerman's cyclical model of self-regulated learning. Anales de Psicologia, 30(2), 450-462. https://doi.org/10.6018/analesps.30.2.167221

Paris, S. G., Lipson, M. Y., \& Wixson, K. K. (1983). Becoming a strategic reader. Contemporary Educational Psychology, 8(3), 293-316.

Rosenshine, B., \& Meister, C. (1994). Reciprocal teaching: A review of the research. Review of Educational Research, 64(4), 479-530.

Royse, D. D. (2001). Teaching tips for college and university instructors: A practical guide. Allyn \& Bacon.

Utami, Y. P., \& Sugirin, S. (2019). Fostering Students' Reading Comprehension Ability through Directed Reading Thinking Activities (DRTA) Strategy. Journal of English Language Teaching and Linguistics, 4(2), 129. https://doi.org/10.21462/jeltl.v4i2.250

Wandler, J. B., \& Imbriale, W. J. (2017). Promoting undergraduate student self-regulation in online learning environments. Online Learning Journal, 21(2). 